症例

内視鏡下の異物摘出で治癒した魚骨による胃穿孔の 1 例

岐阜大学医学部附属病院高次救命治療センター, 岐皁大学医学部腫場外科*

$$
\begin{aligned}
& \text { 安藤公隆松橋延壽宮原利行 } \\
& \text { 山口和也*森義雄 小倉真治 }
\end{aligned}
$$

68歳, 女性. 主訴は下腹部痛. 平成16年 6 月 8 日下腹部痛が出現し, 近医を受診して 腹膜炎を疑われ当院紹介受診となった。腹部 CTにて胃前庭部に $3 \mathrm{~cm}$ の高吸収域を呈 する異物による線状陰影を認め、この異物は胃壁を貫通して周囲には腹空内遊離ガス像 を伴っていた。発症前日夕にぶりを食へていたことが判明し，緊急 GIF を施行したとこ ろ, 胃前庭部前壁幽門輪近傍に魚骨が刺入しており，魚骨による胃穿孔とこれに伴う限 局性腹膜炎と診断された．内視鏡下に魚骨を除去し，入院の上保存的治療を行って第10 病日に内科に転科した，魚骨による胃穿孔は稀な疾患とされ，本邦での報告例は自験例 も含め23例ある.ほとんどの症例が開腹手術を施行されているが, CT 所見より魚骨の存 在は診断可能であり，発症早期であれば内視鏡による魚骨の除去と抗生剤投与による保 存的治療が第一選択となり得る可能性があると考えられ, 若干の文献的考察を加えて報 告する.

㮂引用語 : gastric perforation, fish bone, conservative therapy

\section{緒 言}

愦飲した魚骨による消化管穿孔・穿通は稀な疾患で あるが, 多くは下部消化管の穿孔・穿通であり, 胃で は非常に稀である。このため確診は困難であるとさ れ"これまでの魚骨胃壁穿孔・穿通の報告例のほとん どが開腹手術を施行されている. 今回われわれは，腹 部 CT 所見より診断し，内視鏡下に魚骨を摘出して保 存的治療によって治痹することができた魚骨による胃 穿孔の 1 例を経験したのて，若干の文献的考察を加え て報告する。

症例：68歳, 女性.

\section{症例}

主訴：下腹部痛.

既往歴：既往歴に急性虫垂炎に対する虫垂切除術 (25歳頃), 左乳癌に対する左乳房切断術 (40歳頃), 高血圧, 高脂血症, 多萲胞腎, 左腎動脈瘤があり近医 通院中である.

家族歴：特記すべきことなし.

2005年 3 月 29 日受付 2005 年 7 月 27 日採用

〈所属施設住所〉

厂501-1193 岐皁市柳戸 $1-1$
現病歴：平成 16 年 6 月 8 日朝より持続性の下腹部痛 が出現したが, 悪心嘔吐は伴わず昼食も摄取可能であ つた。しかし，腹痛が徐々に增悪したため同日夕方に 近医を受診したところ，下腹部に腹膜刺激症状を認め 発熱を伴っていたため，腹膜资を疑われて当院を紹介 受診した。

来院時現症: 体温 $37.3^{\circ} \mathrm{C}$, 脈拍 $101 / \mathrm{min}$, 血圧 $176 / 77$ $\mathrm{mmHg}$, 腹部は全体に軽度膨隆し, 腸蜻動音は減弱, 腹部全体に圧痛を認め，上腹部には強い反跳痛と筋性 防御を伴っていた。

血液生化学検查所見：WBC $9.060 / \mathrm{mm}^{3}$, CRP 0.88 $\mathrm{mg} / \mathrm{dl}$ と炎症反応の軽度上昇を認めた。

胸腹部単純 $\mathrm{X}$ 線写真所見：わずかに小腸ガス像を 認めるものの, 横隔膜下の遊離ガス像や胸水貯留は認 めなかった。

腹部単純 CT 所見：胃前庭部に長さ $3 \mathrm{~cm}$ の高吸収 域を呈する線状陰影を認め, 異物の存在が疑われた。 この異物は胃壁を貫通し先端は腹腔内に脱出して, 周 囲にはわずかな腹腔内遊離ガス像を認めた（Fig. 1).

腹部 CT 所見より, 胃内の異物による胃穿孔が疑わ れたため，緊急上部消化管内視鏡検査を施行した。

上部消化管内視鏡検査所見：胃前庭部前壁幽門輪近 
傍に魚骨と思われる異物が刺入しており（Fig. 2a）, これを銝子で把持して除去した（Fig. 2b). 魚骨除去 後の穿孔部 (Fig. 3a) は, メタルクリップ 2 個にて縫 縮しておいた (Fig. 3b).

内視鏡による処置後, 再度患者より食事歴について 聴取したところ, 発症前日の夕食で魚（ぶり）を摄取 していたことがわかった。

以上より，魚骨（ぶり）による胃穿孔とこれに伴う 限局性腹膜炎と診断した。

穿孔部はクリッピングにより閉鎖され，腹膜炎は限 局していると考えられたこと, 発症から12時間以上が

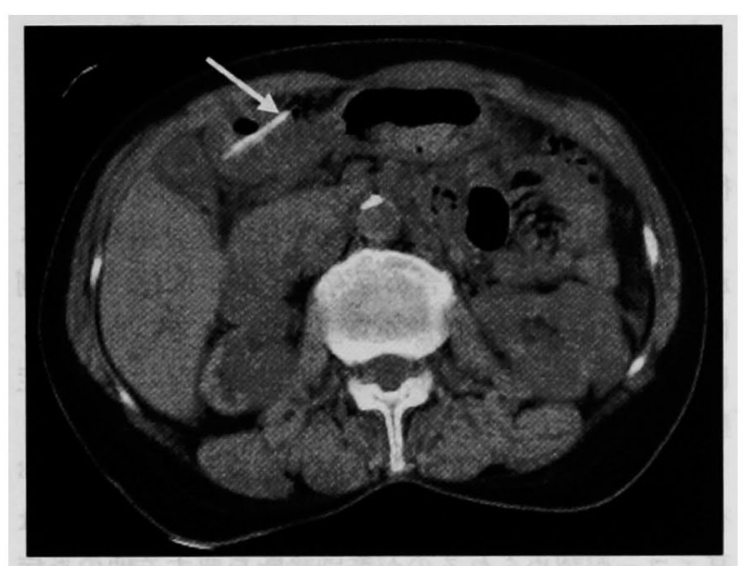

Fig. 1 Abdominal CT showed a linear high density structure in the prepyloric region of the stomach (arrow). The structure penetrated through the gastric wall and abnormal air collection was identified around its tip.
経過しても血液検査所見上の炎症所見は軽度であり全 身状態も良好であることから, 入院の上保存的療法を 行うこととした。

入院後経過：入院後は絶飲食, 抗生剂投与, 経鼻胃 管による减圧を行ったところ，翌日からは解熱傾向， 上腹部の圧痛部位の縮小, 炎症所見の消退を認め, 上 腹部の圧痛が消失し炎症所見がほほ陰性となった 6 月 14日（第 7 病日）より経口摄取を再開したが, 腹痛や 発熱は出現しなかった。 6 月16日（第 9 病日）に施行 した腹部 CT 所見では, 胃前庭部のクリップが確認さ れ，周辺には腹腔内遊離ガス像や膿瘍形成を疑わせる 低吸収域は認めず (Fig.4)，胃穿孔と腹膜炎は治瘜し たと判断された。なお, 胸部 CTにて左肺に $25 \mathrm{~mm}$ 大 の腫瘤影を認めており，6月17日（第10病日）に肺腫 瘤の精査目的で呼吸器内科へ転科した。

\section{考察}

誤飲した消化管異物の多くは消化あるいは自然排泄 され，消化管穿孔などの合併症を起こすことは少なく $1 \%$ 以下とされている2)31.この中で，消化管穿孔・穿 通の原因となる異物は, 欧米では爪揚枝・鳥骨が多 く45)，本邦では魚骨が多く49\%を占める6)といわれて いる. 部位別の頻度については，松井ら”は123例につ いて報告し，肛門 $(22.0 \%) ，$ 横行結腸 $(16.3 \%) ， \mathrm{~S}$ 状 結腸 $(8.1 \%)$ ，回腸 $(6.5 \%)$ の順に多く，胃穿孔例は $1.6 \%$ とている.また, 安東ら ${ }^{8)}$ の報告では240例の中 で, 食道 $(18.1 \%)$ ，回腸 $(14.9 \%)$ ，横行結腸 $(12.0$ \%)，胃 (8.7\%) の順に多いとして损，魚骨による 胃穿孔は稀な疾患であると考えられる。

今回, 医学中央雑誌およびMEDLINEで検索しえ

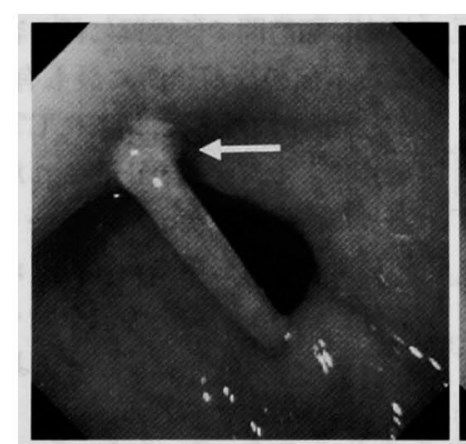

a

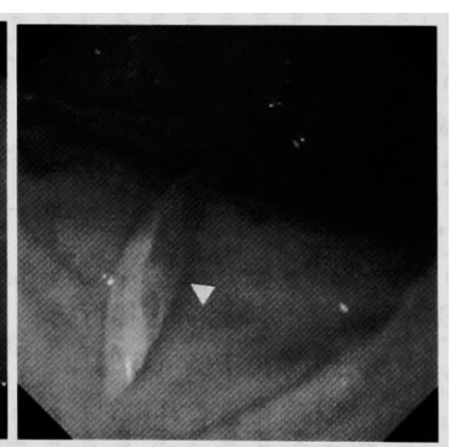

b

Fig. 2 a) Endoscopic examination revealed a fish bone stuck in anterior wall of prepyloric region of the stomach (arrow). b) A fish bone (arrow head), $3 \mathrm{~cm}$ in length, was removed from gastric wall endoscopically. 


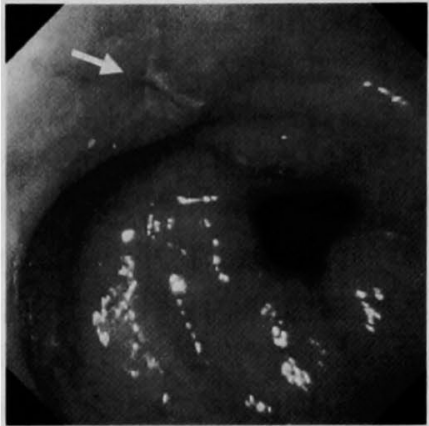

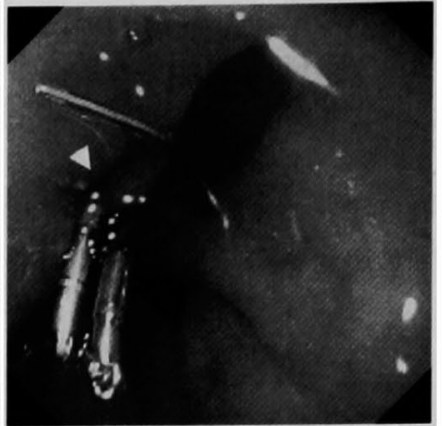

b

Fig. 3 a ) After removal of the fish bone, there was an ulcerative lesion (arrow). b) The ulcerative lesion was clamped by metal clips (arrow head).

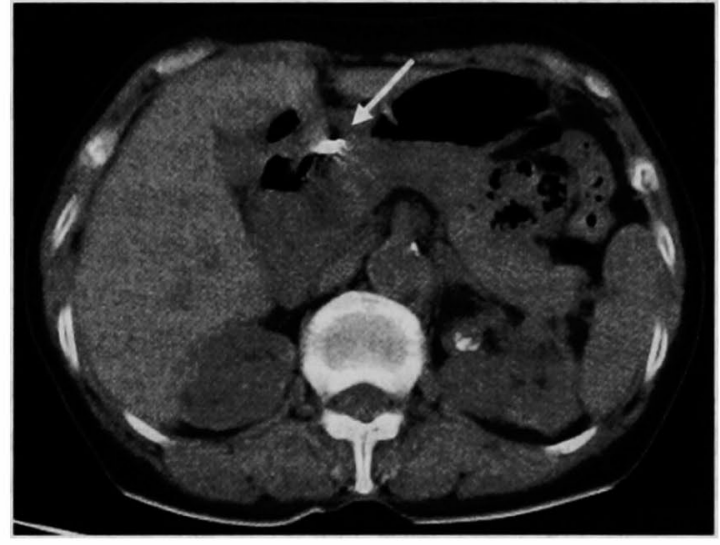

Fig. 4 Abdominal CT taken 8 days after admission, showed residual metal clips on the gastric wall (arrow), however neither abnormal air collection nor abscess was detectable in abdominal cavity.

た限りでは，魚骨による胃穿孔の本邦報告例（以下本 症と記す) は自験例を含めて23例1)であった(Table 1). 開腹, 腹腔鏡下を含めて手術を施行されたものが20例 (87\%) で，その内訳は，魚骨除去 5 例 (25\%)，幽門 側胃切除術 4 例 $(20 \%)$ ，膿場切除 4 例 $(20 \%)$ ，穿孔 部単純縫合閉鎖 4 例 (20\%), 幽門側胃切除術と横行結 腸部分切除 1 例 ( $5 \%$ ), 胃局所切除術 1 例 ( $5 \%$ ), 洗浄とドレナージ 1 例 $(5 \%)$ であった。これに対し， 保存的治療が行われたのは 3 例 $(13 \%)^{1199}$ であったが, 全例が内視鏡による魚骨の除去を施行されており，内 視鏡的に魚骨を除去しえたのは全体で４例（17 \%) 191101であった。

本症の発症形式は，穿孔後体腔内に急激に炎症が波
及し腹膜炎・胸膜炎・縦隔炎を生ずる急性炎症型と, 徐々に炎症所見が発現し膿瘍や炎症性肉芽腫を形成す る慢性炎症型に大別され，本邦では慢性型が多いとさ れている ${ }^{8)}$. 自験例を含め保存的治療が行われた 3 例 は, いずれも魚骨の誤飲から症状発現までの時間が 3 日以内と短く, 膿瘍形成などの合併症がない急性炎症 型であることが特徴である.

本症の診断には CT 検查, 腹部超音波 (US) 検查が 有用であるとされ，魚骨による線状の高吸収域または 高エコーが認められるのが鑑別診断を要する他の炎症 性疾患や腫瘍ではみられない特徵的な所見であ $3^{(1) \sim 14)}$. 従来, 本症の術前の確診は困難であるとされ てきたが，近年画像診断の進歩に伴い術前の正診率は

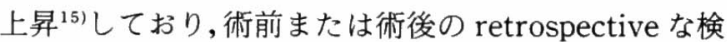
討により診断可能であったとする報告例が多い ${ }^{16}$. CT 検査は短時間で低侵襲に行え客観性があり，現在のと ころ本症の術前診断に最も有用とする報告 ${ }^{15)}$ がある が, 今回の検討では, 術前にCT あるいは US 所見から 魚骨による胃穿孔と正診されたものが17例（73\%）で あった. 術後の retrospective な検討も含めると, 内視 鏡による魚骨の除去後に CT が施行された 1 例と CT が施行されていない 4 例を除く全例で特徵的所見を認 めていることから, CT 所見より魚骨の存在は診断可 能であると考えられる。

以上より，魚骨による胃穿孔は，詳細な病歴（特に 食事歴の）聴取と腹部 $\mathrm{CT}$ 検查, 上部消化管内視鏡検 査により診断可能であると考えられた。また，胃内の 魚骨は内視鏡で除去可能であり，急性型で膿瘍などの 合併症を伴わなければ，自験例のように抗生剤投与に 


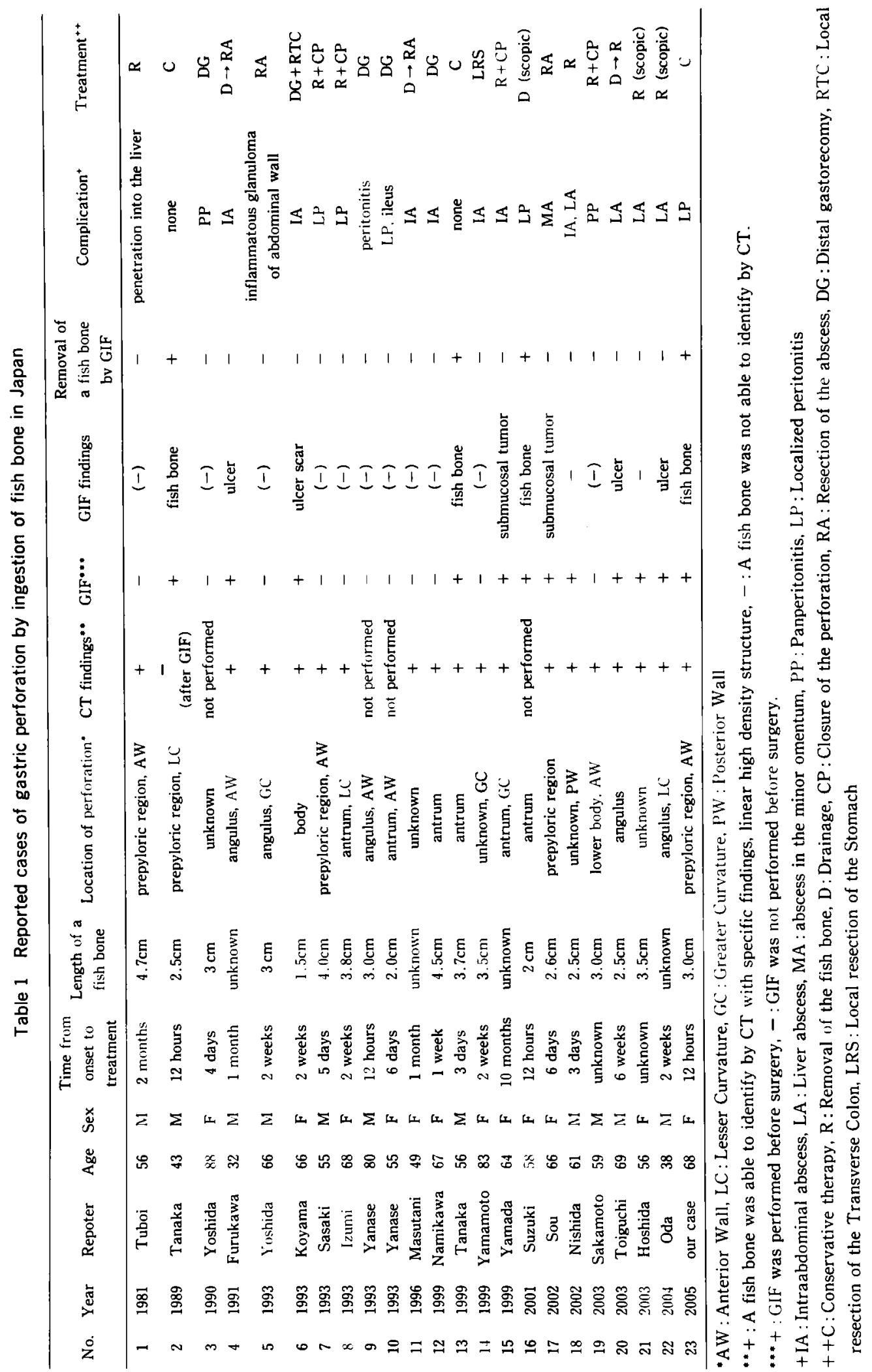


よる保存的治療でも充分であると思われる。鈴木ら10) は内視鏡による魚骨の除去後に手術を施行した 1 例を 報告し，腹腔内の炎症性変化はごく軽度であったとし ており，魚骨に上る胃穿孔は，発症後早期であれば内 視鏡による巽物除去と抗生剤投与による保存的治療が 第一選択となり得ると考えられた。

$$
\text { 結 語 }
$$

内視鏡による異物除去と抗生郕投与による保存的治 療が奏効した魚骨による胃穿孔の 1 例を経験したので 報告した。魚骨による胃穿孔は, CT 所見より診断可能 であり, 発症後早期て膿瘍形成などの合併症を伴わな ければ，内視鏡による異物除去と抗生剤投与による保 存的治療が第一選択となり得ると考えられた.

なお、本論文の要旨は第 8 回日本臨床救急医学会総会 (2005年 4 月，東京）において発表した。

$$
\text { 文献 }
$$

1）田中洋一, 宮崎修一, 福田 保他: 内視鏡下に摘 出した魚骨男壁穿通の 1 例. Gastroenterol Endosc 41:1474-1477, 1999

2) Perelman $\mathrm{H}:$ Toothpick perforation of the gastrointestinal tract. J Abdom Surg 4: 51-53, 1962

3) Mcpherson RC, Karlan M. Williams RD: Foreign body perforation of the intestinal tract. Am J Surg 94: 564-566, 1957

4) Ward-McQuaid JN : Perforation of the intestine by swallowed foreign bodies. Br J Surg $37: 349-351,1952$

5) Sterry AB, Hunter-craig ID: Foreign-body perforation of the gut. Br J Surg $54: 382-384$. 1967

6）石橋新太郎：腹旺内異物に関する臨床的並びに実
験的研究. 日外会誌 $62: 489-509,1961$

7）松井昭彦, 岡島邦雄, 川西端哉他：魚骨による消 化管穿通の 2 治酫例一症例報告ならびに本邦報告 121例の検討一。臨外会誌 $47: 955-961 ， 1986$

8）安東俊明, 恩田昌彦, 森山雄吉他：誤䓵魚骨に上 る消化管穿孔，穿通の 3 例. 日消外会誌 $23: 889$ $-893,1990$

9）田中松平，金子芳夫，家接健一他：魚骨による胃 穿孔を起こした 1 例 上部消化管異物の内視鏡的 摘出に関する考察. 北陸外科会誌 $9: 79-82$, 1990

10）鈴木敬一朗，安櫴貫年，龟村幸平他：魚骨による 胃穿孔の 1 例．消内視鏡 $13: 834-835 ， 2001$

11）竹元伸之, 山本 宏, 甲斐敏弘他：術前診断が可 能であった魚骨による腹腔内炎症性腫窗の 1 例。 日臨外会誌 $61: 1293-1298,2000$

12）津田基晴, 鈴木 衛, 小山信二他：CT スキャンに よって術前に診断した魚骨穿通による腹腔腫墳の 1 例。臨外 $52: 1213-1216,1997$

13）星野和義，村上雅一，塩田摄成他：特徽的な画像 を呈した魚骨の消化管穿通による腹腔内脹鸹の 1 例. 臨外 $53: 1343-1346,1998$

14）穂坂則臣, 杉田 昭, 深沢信悟他：魚骨の消化管 穿通による腹望内腫瘤の 1 例。日臨外会誌 57 ： $1668-1671,1996$

15）宗 淳一, 未光浩也, 中島裕一他：CTにて術前診 断しえた魚骨による胃穿孔の1例. 雲南病医誌 $10: 9-13,2002$

16）吉光 裕, 安田雅美, 天谷公司 他：保存的に治痖 した魚骨の消化管穿孔による腹腔内脤瘍の 1 例。 臨外 56：1561-1564, 2001 


\title{
A CASE OF SUCCESSFUL CONSERVATIVE THERAPY FOR GASTRIC PERFORATION BY AN INGESTED FISH BONE
}

\author{
Masataka ANDO, Nobuhisa MATSUHASHI, Toshiyuki MIYAHARA, \\ Kazuya YAMAGUCHI*, Yoshio MORI and Shinji OGURA \\ Advanced Critical Care Center, Gifu University Hospital \\ -Department of Surgical Oncology, Graduate School of Medicine, Gifu University
}

\begin{abstract}
A 68-year-old woman complaining of lower abdominal pain was admitted to the hospital with a suspicion of peritonitis 12 hours after she ate a fish (yellowtail). Abdominal CT scan showed a linear high density structure in the prepyloric region of the stomach. Endoscopic examination revealed a fish bone stuck in the anterior wall of prepyloric region of the stomach. The fish bone, $3 \mathrm{~cm}$ in length, was removed from the gastric wall endoscopically. From those studies, she was diagnosed as having localized peritonitis due to gastric perforation by the ingested fish bone and conservative therapy with antibiotics was started. The clinical course was satisfactory and uncomplicated. Abdominal CT taken 8 days after admission showed neither abnormal air collection nor abscess in the abdominal cavity. She was transferred to the department of internal medicine from our department on the 10th hospital day. In a review of the literature, 23 cases of gastric perforation by an ingested fish bone, including our case, have been reported, and among of then, successful conservative therapy has been done in few cases. Although gastric perforation by an ingested fish bone had been treated by surgery, endoscopical removal of the fish bone and conservative therapy with antibiotics may become the first choice of therapy for the disease.
\end{abstract}

